\title{
The Judicialization of Territorial Politics in Brazil, Colombia and Spain*
}

\author{
Helder Ferreira do Vale \\ Spanish Center for Political and Constitutional Studies (CEPC), Spain
}

\begin{abstract}
This article explains how judicial review influences intergovernmental political dynamics in Brazil, Colombia and Spain. The argument is developed in light of two questions: how supreme courts have established themselves as pivotal institutions for settling vertical intergovernmental disputes, and how national and subnational politicians use judicial review in order to enhance their own interests. A comparison between the judicial review processes in federal Brazil, quasi-federal Spain, and unitary Colombia provides an answer to these questions. Accounting for the differences in the territorial organization and systems of government among these countries, the article assesses the patterns of judicial review originating from the subnational level. Findings suggest that courts affect the interaction between national and subnational politicians in the three country-cases, but through different patterns of judicialization of territorial politics.
\end{abstract}

Keywords: judicial review; constitutional change; intergovernmental relations; territorial politics; decentralization

\section{Introduction}

ince the enactment of their most recent constitutions, Brazil, Colombia and

$\checkmark$ Spain have undergone important processes of constitutional judicial review. This article assesses the patterns of judicial review of national legislative initiatives originating from the subnational level, taking into account the differences in the territorial organization and systems of government of these countries.

1 The data necessary to reproduce numerical results can be found in http://bpsr.org.br/files/arquivos/Banco Dados_Vale.xlsx 
The ultimate goal here is to understand how intergovernmental relations relate to the process of judicial involvement in territorial affairs in different institutional settings. More specifically, the article intends to establish a relationship between constitutional judicial review and intergovernmental disputes in the selected countries. With this goal in mind, the article analyzes the instruments used by subnational politicians to challenge policies by the central government. The aim is to show the increasing displacement of conflict to the courts in matters concerning territorial governance. This article does not attempt to explain the decision-making process of judges.

In light of this goal, this article touches upon two pressing questions of territorial politics: how supreme courts have established themselves as pivotal institutions in dispute settlement concerning territorial politics, and how national and regional politicians attempt to use intergovernmental mechanisms to enhance their own interests through judicial review. Considering the differences between Brazil, Colombia and Spain, these questions will serve as a general guideline for understanding two aspects of the judicialization of politics: when plaintiffs bring territorial issues to courts, and how the structure of the judiciary shapes intergovernmental relations.

Judicial inroads into politics are receiving growing attention from scholars. Most analyses focus on the impact of the blurring of boundaries between political and judicial dynamics on democratic development. Analysts indicate that the more prominent role of the judiciary influences political dynamics in different ways: it affects the decision of voters to select political leaders (Fox and Stephenson, 2011); it impacts legislative decisions in a competitive political environment (Rogers, 2001); it has the potential to work as an insurance mechanism for policy continuity in situations of adverse electoral outcomes (Tridimas, 2010); and it fosters political centralization (Vaubel, 2009). Disputes related to the Legislative branch have been brought before constitutional courts, changing the way in which conflicts have been commonly resolved. Courts are increasingly involved in disputes between central and subnational governments, implying that in territorial politics, courts are having a determining role in conflict resolution.

In an attempt to show the judicialization of territorial governance, I will base the analysis on three countries with different territorial arrangements: federal Brazil, quasi-federal Spain, and unitary Colombia. Although the selected countries show important differences from each other that are not limited to territorial organization (e.g., systems of government, party system, modes of interaction between central and subnational governments, patterns of territorial conflict), they all have common mechanisms for intergovernmental dispute settlement to initiate a process of judicial review. More specifically, they all have in common some institutional features of judicial independence - e.g., autonomy of the judiciary and external appointment by one branch of government -, which has favored 
a growing involvement of the courts in territorial politics. However, they present varying structures of judicial review - e.g., constitutional arrangements, actors who can exercise the right of a plaintiff, scope of judicial power, etc. As a consequence, in Brazil, Colombia and Spain, a greater utilization of judicial review as an instrument of conflict resolution has produced different patterns of judicial review.

Why have Brazil, Colombia and Spain been chosen for this study? Firstly, in these countries, the process of judicial review is the result of a democratic choice in critical moments of political transition. In Brazil and Spain, judicial review became an instrument for settling disputes in order to implement democratic constitutions in the aftermath of the transition to democracy. Similarly, in Colombia, the judicial process became an important element for implementing a constitution in the midst of a civil conflict.

Secondly, these countries are conspicuous cases of judicial review in their respective regions. They have become regional leaders in the use of this process. Brazil and Colombia are the Latin American countries in which the courts are most engaged in the judicial review process (Stein and Tomasi, 2006: pp. 83). In Europe, Spain has rapidly adopted a strong system of judicial review since its transition (Ginsburg, 2002), and in the western European context, it has become a notable case of a country in which political disputes often end up in the courts (Guarneri and Pederzoli, 2002).

In order to show the growing role of the judiciary in territorial politics in Brazil, Colombia and Spain, this article proceeds in three steps. Firstly, it argues that judicial review is in effect a process of constitutional review with important implications for vertical intergovernmental relations in the countries in question. Secondly, it shows that contention over issues affecting territorial governance in Brazil, Colombia and Spain increased due to the reactions of subnational governments to central government policies. And, thirdly, it demonstrates that in the three countries, territorial cleavages over varying issues have increasingly been decided in the courts, indicating the contentiousness of territorial issues and the inability of conventional political channels to resolve certain disputes.

\section{Assessing Constitutional Judicial Review and Intergovernmental Relations}

How can judicial review be considered a process of constitutional change? What is the link between constitutional judicial review and intergovernmental relations? In this article, judicial review is interpreted as an instrument not only of law enforcement but also of lawmaking. As such, constitutional review is presented as an interpretative process carried out by means of the mechanism of judicial review. This notion of constitutional review is associated with intergovernmental relations in the following way: in the implementation of 
the constitution, bargaining among intergovernmental actors can lead to contention and to the pursuit of diverging intergovernmental interests, which, in turn, push different intergovernmental actors into pursuing an amendment of the constitution on their own terms.

The above argument is based on a paradigm that interprets the process of judicial review as a democratically and politically constructed process (Graber, 2005). This paradigm is also built on the idea that the political realm is increasingly judicialized, a phenomenon coined in the expression 'the judicialization of politics,' as Vallinder (1995) has put it. Moreover, for Tate and Vallinder (1995), this judicialization of politics is correlated with the politicization of justice, and is the reflection of the expansion of the judiciary in modern democracies (Maciel and Koerner, 2002).

As this article also considers the judicial branch to be an institution of prime importance politically, I suggest that supreme courts have a role that goes beyond the more traditional function of checks and balances among governmental branches. By understanding that processes of judicial review have entered the arena of politics, it is possible to see that courts are institutions exercising the potential function of veto players, policy players and societally representative bodies (Stein et al., 2006: pp. 82).

Based on the notion of the judicialization of politics, the definition of judicial review adopted in the article is borrowed from Tate (1995:28). He defines judicial review as a process of greater involvement by courts and judges in the decision-making behind public policies. This means that the courts are occupying a dominant role in an area that was previously the almost exclusive territory of the legislative and executive branches of government.

By using this definition of judicial review, I assume that the judiciary is vested with the function of constitutional transformation. As the judiciary becomes an active participant in political disputes, it is reasonable to propose that it is competing with traditional institutions in developing and promoting changes in the constitution. This article embraces a broad idea of constitutional change through judicial interpretation, which, as Rasch and Congleton (2006: pp. 324) suggest, entails change without any alteration to the actual constitutional text. Thus, the difference between formal amendments and the judicial interpretation of challenges to the law is related to the explicitness of the process. From this perspective, whenever there is no explicit change in the constitution (e.g., constitutional amendment), judicial review can be considered an implicit form of constitutional review.

Broadly defined, intergovernmental relations can be interpreted as a relationship between different levels of government. Although straightforward, this descriptive definition provides little information about the institutional arrangements shaping this relationship or the political context in which this relationship evolves. Considering both of these factors, intergovernmental relations are understood in this article as a range of interactions 
between goal-oriented governmental actors belonging to different locations in a territorial network structure. Given the actors involved and the potential for shifting loci of authority, the interaction is oriented toward bargaining.

Based on the above definitions, it is worth explaining how these three central concepts -judicial review, constitutional review and intergovernmental relations - relate to each other. The article establishes the following rationale that links together the terms: in periods following the enactment of democratic constitutions, subnational politicians - who were important engineers of constitutions - attempted to maintain subnational autonomy by fighting any eventual encroachment of authority through judicial review. Under these circumstances, they started to use constitutionally guaranteed mechanisms to exercise such autonomy. Over time, the settling of disputes had implicitly transformed the constitution. The decisions by courts set a legal framework for the evolution of intergovernmental relations.

This logic is supported by Ginsburg's (2003) insurance argument, according to which judicial review is put in place after a constitutional pact is reached, so that all parties involved in the pact can be assured that, once in power, no individual party will make drastic constitutional changes altering the initial constitutional order. ${ }^{2}$

This insurance argument is consistent in the cases of Brazil, Colombia and Spain. In Brazil and Spain, for example, the pact reached among political elites during their respective transitions to democracy had to be protected through the courts, as certain parties feared an eventual encroachment of power. Similarly, amid political upheaval in 1991, Colombia engineered a new constitution, which also needed to be protected from eventual encroachment.

In addition to the insurance argument, one can complement the explanation of how in the three country-cases judicial review fits the larger picture of constitutional change with the so-called theory of renegotiation, as put forward by Elkins et al. (2009). These authors put forward the argument that constitutions can either be entirely replaced or amended. In the latter instance, in which the cases of Brazil, Colombia and Spain fall, depending on the breadth of participation in the phase of constitutional formulation (inclusion), the level of detail (specificity) and the adaptation of parts of the constitutional text (flexibility), the constitution will endure. The durability of the constitution, however, will be achieved through the amendment of its text, which can take the form of explicit change or interpretative change, as previously explained.

Based on these criteria, one can assess these principles of inclusion, specificity and flexibility considering territorial and intergovernmental aspects of the constitutional texts of Brazil, Colombia, and Spain. 
From a territorial point of view, inclusion in the initial phase of constitutional elaboration sets the foundations for acceptance and implementation of the constitution. In order to become effective in the intergovernmental sphere, the principle of inclusion must take into account subnational territorial interests in the constitution-making phase. These interests were present from the very inception of the constitutional negotiations in Brazil and Spain through political parties. In Brazil, the states and municipalities obtained important concessions (Souza, 1997). In Spain, the regions are managed in an asymmetrical manner in order to have their voices heard, at the expense of the municipalities (Carrillo, 1997). Similarly, in the negotiations leading to the promulgation of the 1991 Colombian constitution, the regions (departamentos) gained important political powers (e.g., direct elections for regional governors, right to pass regional legislations). In Colombia, the rural-urban divide, which was a leading issue in the constitutional negotiations (Nielson and Shugart, 1999), led to the introduction of decentralizing measures.

As far as the principle of specificity is concerned, and the different territorial arrangements between these countries notwithstanding, the Brazilian, Colombian and Spanish constitutions establish responsibilities for each level of government. The Brazilian constitution lists the exclusive responsibilities of the central, state and municipal governments, as well as the shared responsibilities. Similarly, the Spanish constitution specifies the responsibilities of the national, regional and local governments. Although it designed a unitary system of government, the Colombian constitution enshrines the functional responsibilities of the regional and municipal governments.

In terms of flexibility, the right to adjudication is indeed an important sign of flexibility that has been crucial for settling intergovernmental disputes in the three countries. In Brazil, judicial review is exercised through the Direct Acts of Unconstitutionality (Ações Diretas de Inconstitucionalidade - ADI's) and the Declaratory Acts of Constitutionality (Ações Declaratórias de Constitucionalidade - ADC) filed at the Brazilian Supreme Federal Court (Supremo Tribunal Federal - STF). ${ }^{3}$ These two instruments are used in abstract matters, but the former is the main mechanism for intergovernmental dispute settlement. In Colombia, the instrument of judicial review made before the Colombian Constitutional Court (Corte Constitucional - CC) is called the 'appeal for the protection of constitutional guarantees' (acción de tutela). In Spain, the Autonomous Communities (Comunidades Autónomas - ACs) and the central government file challenges in the Spanish Constitutional Court (Tribunal Constitucional - TC), which are termed Positive Conflicts of Competency (Conflictos Positivos de Competencia), as they concern disputes over constitutionally mandated responsibilities for each level of government. Another instrument is the Unconstitutionality Action (Recurso de Inconstitucionalidad), which is used in matters other than the distribution of responsibilities among levels of government. 
Considering that the Brazilian, Colombian and Spanish constitutions are flexible, inclusive and specific, the incentives for amendment rather than replacement are high. Although explicit changes in the constitution in the three countries are possible through formal amendments, they are more frequently used in Brazil and Colombia, while in Spain amendments have been used twice, in 1992 and 2011. The requirements to pass the amendments explain the dissonant use of this instrument across these countries, among which Spain presents the highest barriers to formally amending the constitution, followed by Colombia, and then Brazil. ${ }^{4}$ That said, it is often the case, especially in contentious areas involving intergovernmental relations, that judicial review becomes a crucial instrument for amending controversial territorial matters.

In line with the above argument, it is important to add to Ginsburg's insurance argument and the theory of renegotiation of Elkins et al. that subnational politicians are important players in this game. In Brazil, the executive and legislative branches of the constituent units are the main plaintiffs in judicial review. In Spain, the subnational executives have led the process of judicial review, as they are the main authors of the challenges brought to the constitutional courts. Lastly, in the case of Colombia, most of the laws pertaining to the competence of the provinces have been challenged at the constitutional court.

\section{Dynamics of Judicial Reviews and Intergovernmental Relations in Brazil, Colombia and Spain}

In any federal system a constitutional court helps to define the limits of shared power by settling disputes between levels of government. However, this role of constitutional courts is not limited to federal systems; in unitary systems courts can equally settle disputes between different administrative units. The cases of Brazil, Colombia and Spain show that intergovernmental dynamics in these countries cannot be understood without including their respective constitutional courts as decisive players in territorial politics.

The decisiveness of these courts regarding territorial politics is determined by the pattern behind the initiation of the judicial review and by the main characteristics behind court rulings. In the three cases, data on the challenges for judicial review will shed some light on the main plaintiffs behind the challenges, as well as on the main political patterns behind them. ${ }^{5}$ A longitudinal analysis involving all cases concerning intergovernmental conflict in Brazil, Colombia and Spain shows different patterns. In the Brazilian (19882012) and Spanish cases (1980-2012), the available data concerns the challenges initiated by subnational political actors. ${ }^{6}$ In the case of Colombia (1992-2012), due to restrictions on publicly available data, the information analyzed was the final rulings of the Colombian CC concerning territorial matters. 
As far as the court rulings are concerned, they are analyzed through "landmark court rulings", which are groundbreaking rulings by the Supreme Court concerning territorial challenges. Identifying landmark court rulings is important for recognizing relevant junctures in the recent history of judicial review in the three countries, and the intergovernmental actors favored by the courts. In Brazil and Spain, the subnational governments were favored in their respective landmark rulings, while in Colombia it was the central government (see Table 1).

Table 1. Aspects of Constitutional Judicial Reviews in Territorial Politics in Brazil, Colombia and Spain

\begin{tabular}{cccc}
\hline & Spain & Colombia & Brazil \\
\hline Origin of the territorial conflict & Subnational & Individual & Subnational \\
\hline $\begin{array}{c}\text { Degree of rulings in favor of the } \\
\text { plaintiff }\end{array}$ & Moderate & Low & Moderate \\
\hline
\end{tabular}

Main dimension of the conflict Vertical intergovernmental Vertical intergovernmental Horizontal subnational

The rulings on the challenges were selected based on the salience of the issue and the impact it had on future territorial related sentences.7 In the following subsections, the main patterns and characteristics of the constitutional judicial review process will be identified in each country-case.

\section{Brazil}

The judicialization of politics in Brazil shows that the judicial branch plays an important role in the process of intergovernmental conflict. This role has become particularly noticeable in a context of growing independence of the judicial branch of government (Santiso, 2003). In Brazil, judicial review is exercised through the ADI's filed at the STF.

Based on the STF's database, state governors are the main users of this constitutional instrument, being responsible for on average $26 \%$ of all the unconstitutional challenges brought to the Supreme Court from 1988 to $2012 .{ }^{8}$ The other main plaintiff is the group of national union confederations, accounting for $21 \%$ of all challenges. The figures on the actors that most resort to judicial review mechanisms suggest that state governors are by far the intergovernmental actor most engaged in judicial review in Brazil (see Figure 1). However, it is important to note that $80 \%$ of all of the governors' challenges were against the state legislature, and only $2 \%$ against the national executive and $5 \%$ against the national legislative branch. 
Figure 1. Brazil's Unconstitutional Challenges

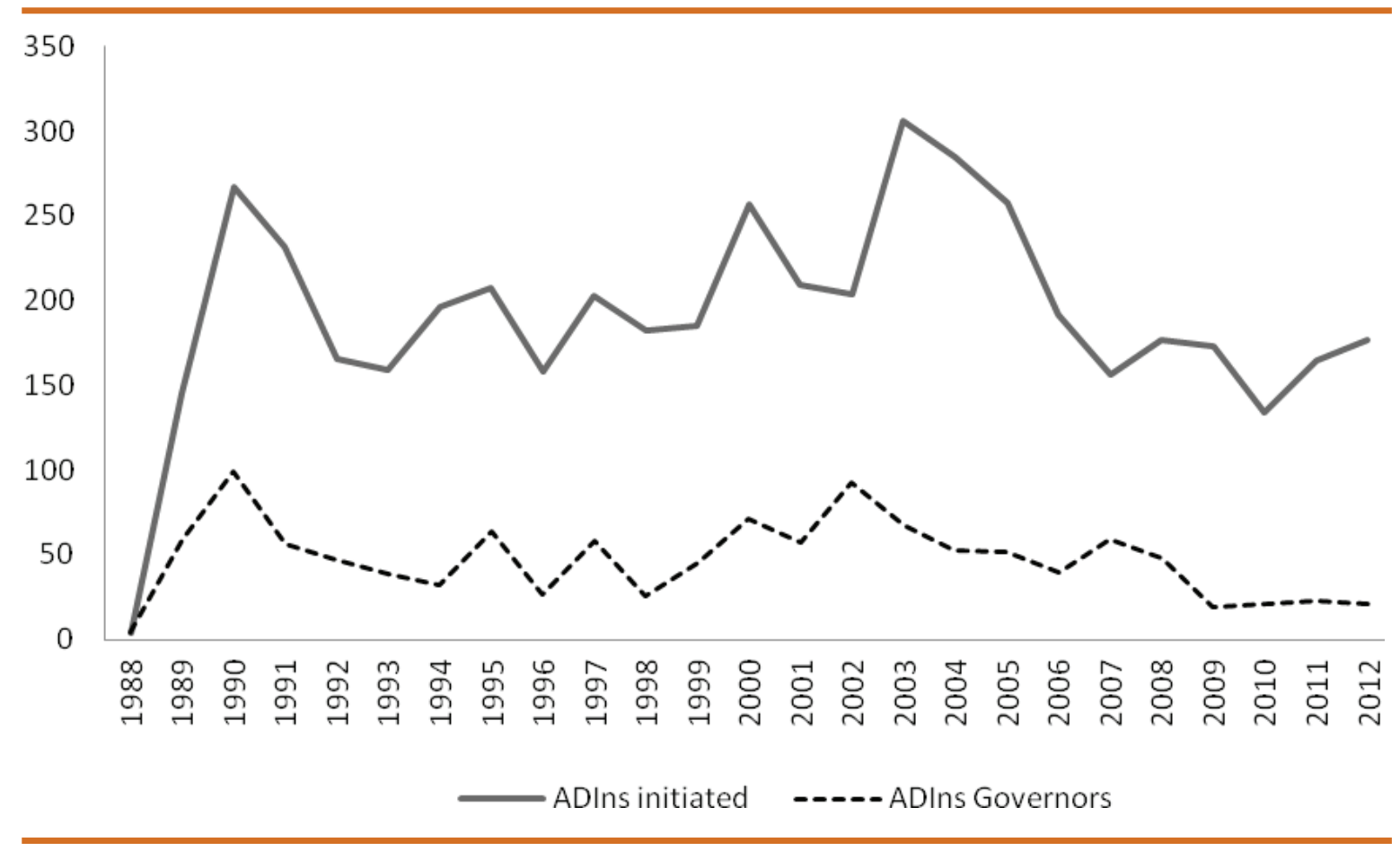

Mapping the origins of the unconstitutional challenges in Brazil, one finds that there is considerable asymmetry in the use of the ADIns by state governors. Most of the challenges come from the southern Brazilian states (e.g., São Paulo, Rio de Janeiro, Espírito Santo, Rio Grande do Sul, Paraná and Santa Catarina), which are responsible for approximately $52 \%$ of all challenges coming from all the Brazilian states, with one state alone, Rio Grande do Sul, responsible for $12 \%$ of all of these challenges.

Considering that the majority of the unconstitutional challenges in Brazil review legislative measures and that the state governors are the main plaintiff, the judicial review process in Brazil has two main characteristics: it is concentrated at the subnational level and it is mainly an inter-branch conflict. These characteristics indicate that judicial review in Brazil is not dominated by intergovernmental disputes. Yet unconstitutional challenges in Brazil have consolidated as an important institutional mechanism at the disposal of intergovernmental actors. In effect, between 1988 and 2012, the national government presented only 8 challenges to the STF, while the state governors presented 1,140 challenges.

The most important challenges that reached the STF concerned financial matters (Kapiszewski, 2011). ${ }^{9}$ Among those, it is possible to consider as a landmark ruling on territorial matters the challenge filed by the governors of Santa Catarina, Paraná, Mato Grosso, Mato Grosso do Sul and Tocantins against Constitutional Amendment 3 of 1993 and Complementary Law 77/9. These legislations created a new tax, the Provisional Tax on Financial Transactions (IPMF), which made it compulsory for states and municipalities 
to pay tax on their financial transactions. The STF declared these legislations unconstitutional on the grounds that no federal constituent unit can impose tax on another. In August 1993, an injunction was granted concerning ADI 926, in order to establish the status quo ante, while the court reached a final ruling on the merits. ${ }^{10}$

Another ADIn that was decisive in the defense of the autonomy of states is ADI 1728 (Maués, 2005). An important Supreme Court decision regarding this was one against a resolution by the Senate (Resolution 117) that determined that $50 \%$ of the states' revenues obtained from privatization should be used to reduce public deficit. Seventeen states supported ADI 1728 contesting the Senate's resolution.

The Brazilian municipalities have also filed ADI's against the national and state governments. There have been several occasions on which the STF has decided in favor of the municipalities. This occurred as the federal states tried the following: to determine the territorial demarcation of certain municipalities (ADI 458); to establish new municipalities without referendum (ADI's 222 and 269); to delimit state intervention on the municipalities (ADI 336); and to regulate the establishment of municipal councilors by number (ADI 204). These examples of judicial intervention show that municipalities have been active in the defense of their autonomy, confirming the observation that municipal autonomy is preserved and defended in Brazil through political review (Araujo, 2005: pp. 26).

The evolution of judicial review in Brazil indicates that after the 1988 Constitution the process gained momentum; however, it has been used with more or less the same frequency. This feature is also applicable to the challenges presented by Brazilian state governors (see Figure 1).

All things considered, the STF has a tendency to favor the executive branch of government. Early findings also support this claim (e.g., Leoni and Ramos, 2006). However, caution is needed when interpreting the role of the STF in a broad area such as territorial matters, which encompass fiscal and administrative issues. Fiscal issues represent $60 \%$ and administrative issues 32\% of the total challenges of judicial review. As a consequence of the wide range of rulings that fall in the territorial matters category, there are important variations in terms of court rulings. There is nowadays an increasing consensus on the fact that the STF exercises restraint in ruling against the executive (Carvalho, 2004; Oliveira, 2006; Vianna et al., 1999). However, after looking at the landmark rulings in Brazil, it can be suggested that state governors have exercised their power as veto players in intergovernmental relations through judicial review. This does not mean that the state governors are always successful; rather, it indicates that they meddle in federal policies aided by the STF.

\section{Colombia}

Since its creation in 1991, the CC has made important inroads into politics. Over time, this court has become an important institution in the Colombian political arena by 
regulating and restricting the presidential power to declare a state of emergency (Uprimny, 2004, 2007: pp. 53), and deciding about the possibility of re-election of the president. The Colombian judicialization of politics is well documented, especially regarding issues pertaining to the state of exception, as well as human and social rights issues. However, the effects of judicialization on the intergovernmental dimension are overlooked in Colombia.

Although Colombia is a unitary state, its regional administrative units, departamentos, as well as the municipalities, are active entities in the attempt to preserve certain responsibilities. In effect, from 1992 to 2012, over 60 laws dealing with the competencies of the regional administrations were brought to the CC challenging their constitutionality. Out of this total, only approximately 20 laws were reviewed by the CC. Even though there is no clear pattern in terms of the evolution of the challenges over time, a trend can be observed - most of the territory-related laws have been contested before the $\mathrm{CC}$, but most of the challenged laws never received a verdict. ${ }^{11}$ As such, the 297 sentences of the CC concerning territorial challenges from 1992 to 2012 account for less than 2\% of the total court sentences issued in this period (See Figure 2).

Figure 2. Rulings of Colombian Unconstitutionally Challenges

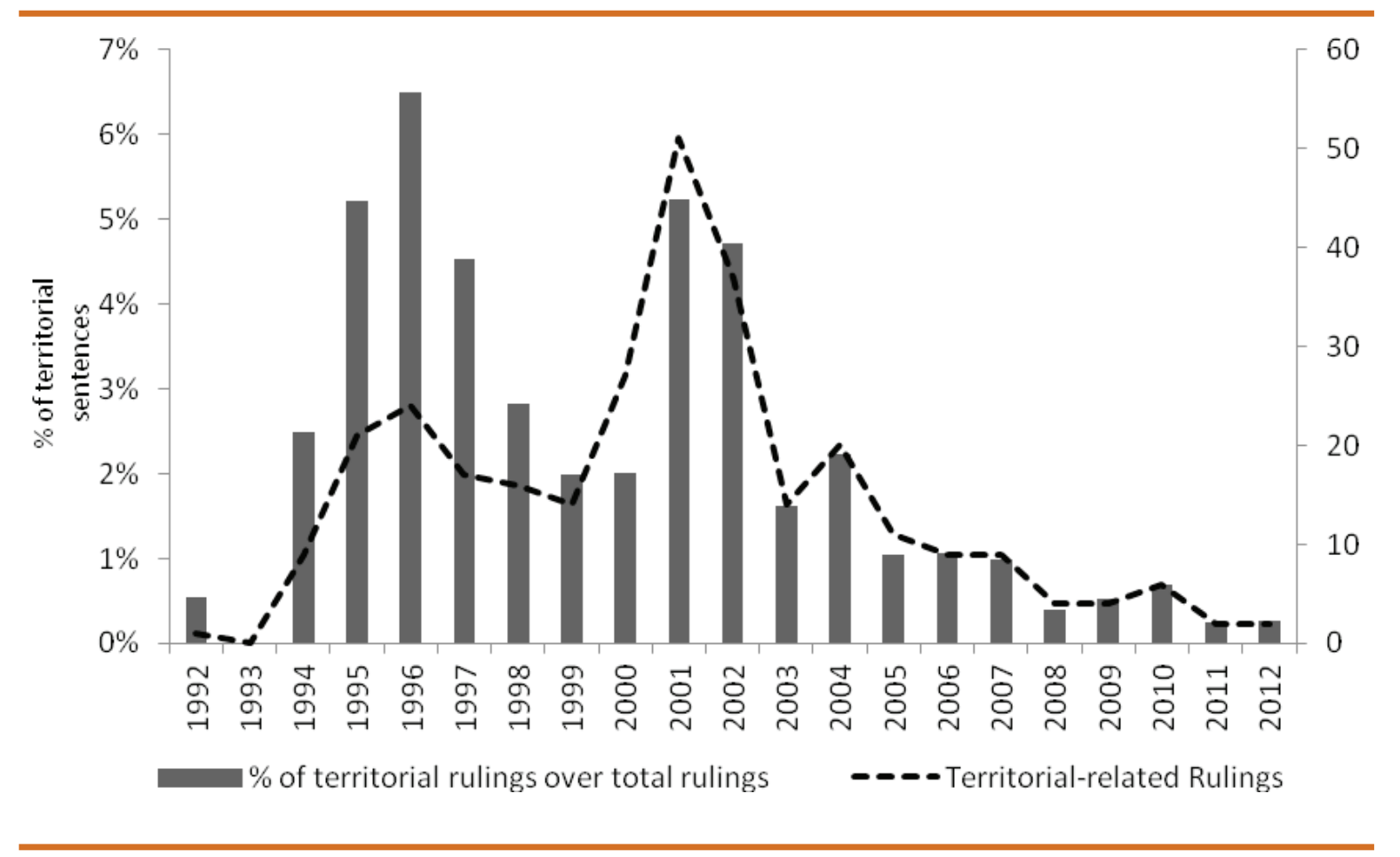

Source: Colombian Constitutional Court

One of the reasons for this sizable number of challenges is the advancement of the decentralization process in Colombia and the wide variety of actors who can make use of the legal instrument of judicial review. Under the 1991 Colombian constitution, which granted substantial power and autonomy to subnational governments, decentralizing reforms 
were launched. With decentralization, the Colombian regions and municipalities gained important functional responsibilities, which were followed by an attempt by the central government to enact new legislative measures to counter the initial local autonomy (Falleti, 2010). To reduce the effect of the decentralizing reforms following the enactment of the 1991 constitution, the central government passed several national legislations from 2000 onwards, triggering the initiation of several constitutional challenges.

The new laws passed by the national government were perceived as diminishing the subnational autonomy acquired with the constitution, while regulating subnational responsibilities. As a consequence, the most contested laws in the CC - e.g., Law 136 of 1994, Law 616, 617, Law 633 of 2000 and Law 715 of 2001 - were laws attempting to establish new administrative and fiscal norms for the regions and municipalities. Laws 136 and 617 attempted to modernize the municipal administration, laws 616 and 633 to regulate municipal fiscal matters, and law 715 regulated municipal responsibilities concerning certain aspects of the delivery of educational services. The laws that received the largest number of challenges were 136 and 715, with 55 and 31 challenges being filed before the $\mathrm{CC}$, respectively.

An explanation for this number of challenges contesting laws of a territorial nature is the fact that in Colombia any ordinary citizen can file a challenge, making access to judicial review very open. Uprimny (2004: pp. 43) attributes the greater involvement of the $\mathrm{CC}$ to this open access. This is important to mention because it is often the case in unitary states that administrative regions and other entities cannot file any challenges. In other words, although Colombian governors and mayors cannot take part in the judicial review process, they individually, as Colombian citizens, can initiate a review process.

Despite this freedom to initiate a judicial review, it is important to mention that the CC can strike down any unconstitutional law for substantial and procedural reasons. In effect, all the territory-related constitutional challenges have been either struck down or the final ruling has favored the central government. In short, so far, no challenge concerning territorial matters has been successful in reverting or amending centrally proposed legislation on territorial matters.

A landmark ruling in Colombia was the CC's decision C-478 of 1992 to reaffirm the unitary character of the Colombian state in a ruling concerning the budget process envisioned in Law 38, passed in 1989. According to Law 38, the revenues and expenditures of the subnational governments can be regulated by the national organic law. With the C-478 ruling, the CC endorses the notion of restrictive autonomy of the budgetary powers of subnational governments while reassuring the central government with the power to sustain the unity and harmonization of the Colombian budgetary system. This ruling set the precedent for future court decisions (e.g., C-720/99, C-897/99, C-579/01). 
Rodríguez-Raga (2006) confirms the proposition that in case of salient legislation for the national government the $\mathrm{CC}$ does not overrule the legislation. Moreover, it rarely rules differently from the Attorney General. ${ }^{12}$ A telling example of the consonance of all the institutions is the recognition by the Colombian constitutional court to uphold Law 796, which called for a referendum on the constitutional reforms in 2003. All the challenges before the court were overridden by judges, reaffirming the support of the court for the national legislative (Cajas Sarriá, 2006: pp. 40). Epstein and Knight (1998) find that the judges in Colombia are in tune with the politicians and other important actors, such as the Attorney General (Procurador General).

All in all, despite being a unitary state and having a rather recent experience with judicial review, challenges before the $\mathrm{CC}$ have shown that there is an increasing judicialization of intergovernmental politics in Colombia due to the open right to initiation. However, the process of judicial review works as an incomplete process of constitutional review, as the general pattern shows that the CC frequently strikes down the challenges. This suggests that whereas the process of judicial review concerning territorial disputes is in place and functioning, it fails to review the claims by plaintiffs being brought to the court. Furthermore, while this pattern indicates that the CC does not change the status quo as it fails to produce an adverse effect other than siding with the Attorney General and striking down the challenges. In other words, judicial review in Colombia has a predictable outcome.

\section{Spain}

The TC can be considered one of the most important institutions mediating relations between the ACs and the central state (Aja Fernández, 1996:129). In effect, the Court has been deemed the single most influential institution in the Spanish territorial system (Aragón Reys, 1986). Constitutional challenges have often been viewed as one of the main instruments for managing conflicts between the central government and the ACs in the face of the generalities of the constitutional provisions in Spain. As the Constitution establishes (Paragraph 3 of Article 149), in matters in which it is not clear whether there is exclusive authority of either the AC or the central government, each level of government can claim authority, although the central government maintains residual authority. This has required the intervention of the TC, which, throughout the 1980s and 1990s, ruled over issues of the ACs' spending, elimination of some taxes, and the redefinition of the ACs' responsibilities.

The governments of the ACs have clearly been the main plaintiffs of the judicial review process. Although the central government has initiated challenges against the ACs, they were less frequent than the AC-led challenges. Only in 1982 did the number of central government challenges exceed those by the ACs. It was in this year that an important 
number of ACs drafted their autonomous statutes. Since these statutes, once approved by the subnational parliaments, have to be endorsed by the national parliament, contentious provisions were brought to the constitutional court. This can be explained in part by the lack of specificity of the Spanish Constitution regarding the process and form through which the ACs can exercise their autonomy.

Considering all the challenges concerning territorial matters, López Guerra considers challenge 32/1981, initiated by the ACs against the Organic Law on the Harmonization of the Autonomic Process (LOAPA), the most emblematic ruling to date. The challenged LOAPA established common norms concerning the implementation of the constitutional responsibilities of the ACs. Creating an important precedent, the TC proclaimed that the LOAPA cannot be enacted as an organic law based on the principle of harmonization. In addition, the TC considered that several provisions of the LOAPA (e.g., Articles 1; 2; 3; 4; 5.1, 2 and 3; 7.1 and 2; 9; 10; 22) encroach on the constitutionally guaranteed responsibilities of the ACs. This is a landmark ruling as it establishes a doctrine of distribution of responsibilities in the Spanish territorial regime, according to which the basic rules of territorial organization in the constitution set out the fundamental norms for the ACs to exercise and further develop their competencies. As a consequence, this sentence has accelerated the process of consolidation of the territorial regime in Spain (López Guerra, 2008).

As far as the activism of the Spanish central government in judicial review is concerned, the national executive presented two successful landmark challenges, 32/1981 and 31/2010, against the ACs. These challenges resulted in two landmark rulings in favor of the central government. Challenge 32/1981 questions the constitutionality of Catalan Law $6 / 1980$ that gives powers to the Catalan government to regulate the provinces under the argument that it violates some constitutional principles. Parts of the law (Art. 1, 2, 3, 5 and 9) were considered unconstitutional as they violate article 142 of the Spanish Constitution, several national laws and article 9.8 of the Catalan Statute of Autonomy.

More recently, in 2010, the TC issued ruling 31/2010 on the challenge initiated by the Spanish central government questioning the legality of the 2006 Catalan Statue of Autonomy. This Catalan legal text has been a source of controversy for its explicit reference to the notion of Catalonia as a nation. In response to this dispute, the TC considered the terms "Catalonia as a nation" and "national reality of Catalonia" used in the preamble of the Catalan Statues juridically inadequate. Moreover, it declared several articles of the Catalan Statute unconstitutional. This ruling, which is considered a milestone in the history of Spanish constitutional law (Villaamil, 2011), affected the future process of judicial review concerning other statutes of autonomy in Spain (Gavara de Cara, 2011). It will certainly have a deterrent effect on any attempt by an AC to vest sovereignty in the 
subnational constituent unit in its preamble. Overall, these two landmark challenges show that the active engagement of the center in resorting to judicial intervention to achieve its preference prevails.

A glance at the map on the origins of the challenges across Spain reveals that there is an asymmetry in the use of judicial review among the ACs. Four ACs constitute $95 \%$ of all the challenges against the central state. Catalonia alone is responsible for $45 \%$ of all the challenges against the central state from 1980 to 2005. The Basque Country comes second with $25 \%$, followed by Galicia with $16 \%$ and Andalusia with $9 \%$. It is not a coincidence that all of these ACs gained access to competencies via the fast-track procedure and were the first ACs to enact subnational constitutions. As these ACs quickly gained responsibilities for a wider spectrum of territorial issues, judicial review became an instrument for resolving conflicts over competency.

As judicial review and the making of territorial arrangements are closely related in Spain, the use of instruments of judicial review abounds in two periods: throughout the 1980s when the territorial regime was being developed; and at the turn of the century, when some ACs started to review their autonomous statutes. These periods show that there is a close relationship between the process of drafting and enacting the statutes of autonomy and the rise in the process of judicial review. The two periods that show the highest number of challenges in the TC coincide respectively with the enactment of the statutes and their reform. In 1985, the year in which the educational and fiscal reforms were introduced, the TC received the highest number of challenges from the ACs in its history. In the 1990s, the challenges led by the ACs were drastically reduced, increasing again in 2003 with the revision of the autonomous statutes in some ACs (See Figure 3).

Party politics have also played an important role in the judicial review process in Spain. In periods in which the non-statewide parties were composing the national coalition government, the challenges brought to court were reduced, though the ACs remained the main users of the judicial review instruments. Under the governments of the Spanish Socialist Party (Partido Obrero Español - PSOE), from 1993 to 1996, and of the Popular Party (Partido Popular - PP), from 1996 to 2000, the Catalan political party - Convergence and Union (Convergencia i Unió - CiU) - was part of the governing coalition. During this period, as long as the $\mathrm{CiU}$ - which was governing Catalonia at the time - belonged to this national governing coalition, the number of challenges brought to the constitutional court was reduced (See Figure 3). 
Figure 3. Spain's Unconstitutionally Challenges over Territorial Responsibilities

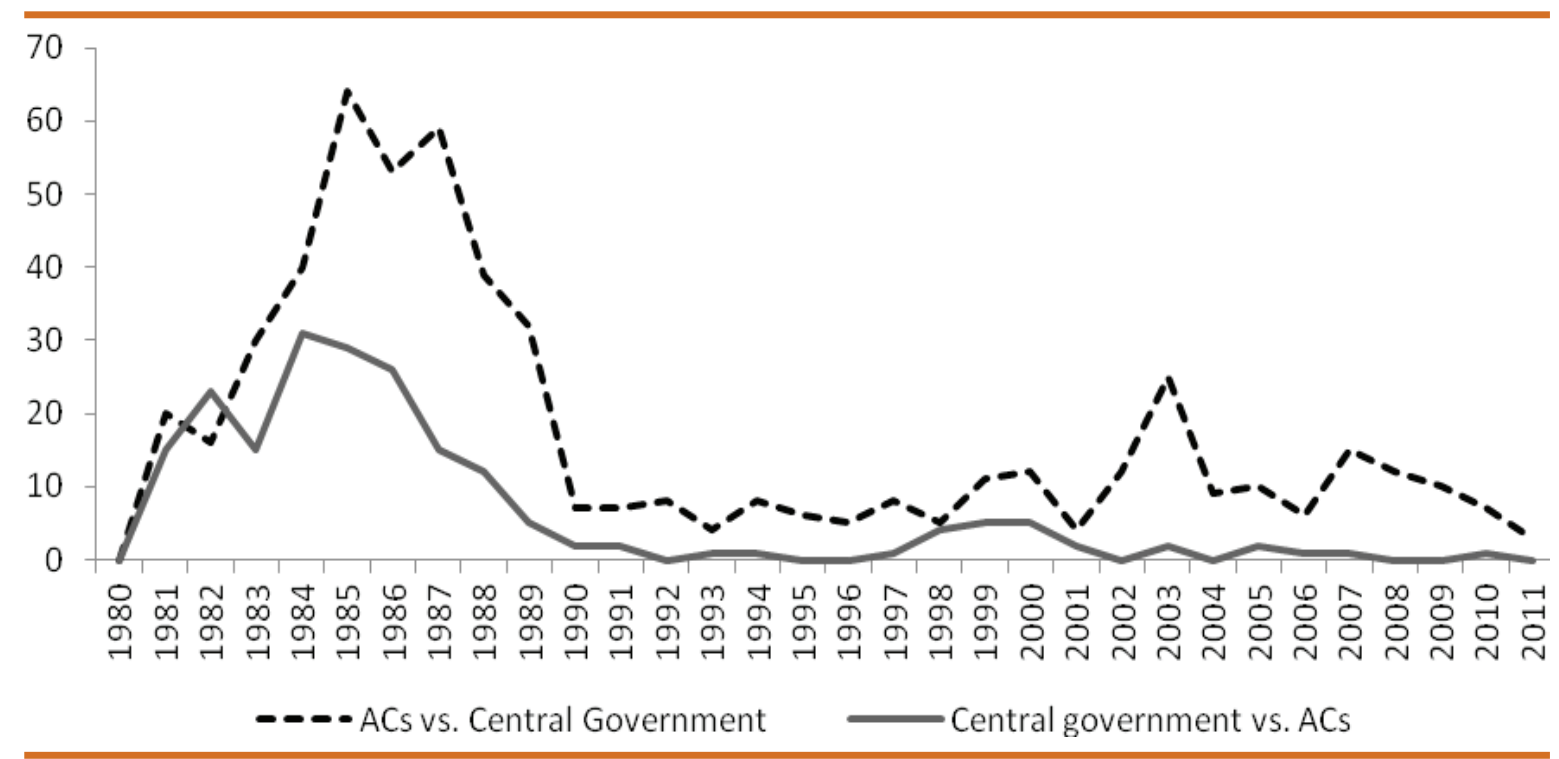

Source: Spanish Ministry of Public Administration, "Conflicto entre el Estado y las Comunidades Autónomas", 2013

It is important to note that the central government also challenged the laws approved by the ACs. However, as Heywood (1995: pp. 20) reports, from 1981 to 1991, while the central government challenged 120 of the more than 1,500 laws approved by regional governments before the Constitutional Court, regional governments challenged 127 of the 528 laws approved by the central state. In light of this evidence, there is little doubt, as Agranoff and Gallarín (1997: pp. 16) point out, that these are important instruments in the hands of the ACs for increasing their share of self-rule. As a result, there are clear indications that judicial review is part of intergovernmental bargaining in Spain.

\section{Discussion}

This article has identified patterns of constitutional judicial review concerning court and plaintiff posturing throughout the judicial review process. The most distinguished feature of judicial behavior in Brazil is the involvement of different branches of government within and across the different levels of government. In Colombia, the most notorious feature is the consistent positioning of the courts with the recommendations of the Attorney General in striking down judicial challenges. In Spain, constitutional judicial review patterns are mainly characterized by a consonance between the governing party at the central level and regional governments. These different distinguishing features point to institutional constraints shaping review processes in different countries.

Although in all the case studies judicial review was introduced against a backdrop of democratization, democratization per se cannot explain the judicialization of 
intergovernmental relations. The democratization approach to judicial review is useful for explaining the initial motivation behind the adoption of judicial review. However, as Hirschl (2008) argues, this approach does not fully explain variations in judicialization among newly democratized countries.

The Brazilian case conforms to the predictions suggesting that in federal countries with horizontal federalism, the different levels of government are more competitive than in countries with vertical federalism (Halberstam, 2008). In effect, under horizontal federalism, different branches of government in the different levels are more likely to pursue their own initiative before courts, just like in Brazil, in which there is a considerable number of challenges initiated by the subnational branches of government. Brazil is known for having a wide number of actors with access to legal instruments for starting a process of judicial review, and, as a result, it is the country with the broadest group standing worldwide (Ríos-Figueroa and Taylor, 2006: pp. 753). In short, in Brazil, horizontal federalism, accompanied by the high group standing, has substantially increased the opportunities for judicial review being initiated at a subnational level.

In Colombia, the main observed pattern of judicial review in matters concerning territorial issues indicates that the courts side with the Colombian president's appointed Attorney General, who, in turn, sides with the national executive. The Colombian case is in line with the predictions suggesting that under hyper-presidentialism (Rose-Ackerman et al., 2011) judges arbitrate in favor of the national executive in matters related to territorial governance. This observation provides evidence for the extraordinary powers of the national executive in Colombia, even in the face of judicial review (Rodríguez-Raga, 2011). With the new constitution, institutional constraints have guaranteed the independence of the Colombian constitutional court, yet the court's judges have been playing strategically by following the recommendations of the Prosecutor General. In other words, the judicialization of territorial politics in Colombia follows a hierarchical decision-making process. This trend is observed in matters concerning territorial issues, marking a stark difference from the involvement of the $\mathrm{CC}$ in areas concerning social policies and the use of the presidential state of emergency powers, where the Court has been playing a counter-balancing role.

In Spain, the type of relationship between central and regional governments has been determinant in the process of judicialization of territorial governance. The proximity of Spanish territorial organization with the vertical federal system creates greater interdependence between central and regional governments. Under vertical federalism, at least in principle, there is greater institutional protection of the interests of constituent units (Halberstam, 2008: pp. 146). As this predicament does not apply to Spain due to the unfinished nature of the territorial distribution of power in the constitution, the TC became not only the defender of the constitution on territorial matters, but also developed 
constitutional matters further based on the judges' own interpretation (Guillén López, 2008). As a consequence, in Spain, judicial review is used when there is greater conflict between the parties governing at the center and the regions. However, as has been previously noted in this article, intergovernmental conflict in Spain can be reduced if the party in the regional government is also in the national government. This implies that in Spain, constitutional challenges are pursued when there is a failure in coordination between central and regional governments. Party politics seem to have influenced this coordination game.

There are several implications behind this mediating role of the judiciary in intergovernmental relations through the supreme courts. Two implications deserve special attention: the fact that courts can be decisive institutions for the intergovernmental balance of power by shaping policies concerning territorial governance; and that they can influence the options and strategies of the national and subnational parliaments and executives.

With regard to the first implication, courts can set the general legal framework of intergovernmental dynamics (Opeskin, 2001: pp. 135). Subnational politicians in Brazil, Colombia and Spain have resorted to judicial instruments for challenging legislation in the supreme courts. Undoubtedly, the supreme courts' rulings over these issues have significant weight on the intergovernmental balance of power. This happens because courts bring stability, as their decisions are final and they do not have an open agenda (Tridimas, 2010: pp. 86). Thus, territorial conflict over issues that cannot be resolved through intergovernmental bargaining are settled by an institution that has a closed and specific agenda.

In reference to the second implication, political actors might build their strategies for political influence by considering the judicial review factor. After all, judicial review itself is constrained in some circumstances (Vanberg, 2001). The process of judicial review, for example, might induce national political actors to engage in strategies to circumvent judicial reviews, such as engaging in amending the constitution, as in the case of Colombia. Another choice is to use judicial review as a process of constitutional change, which is the case of Spain and Brazil. In the latter case, even constitutional amendments are subject to judicial review.

Evidence of the influence of the courts abounds in the three cases. In terms of the intergovernmental balance of power, the courts have favored one level of government over the other in the long-run (see Table 2). 
Table 2. Landmark rulings initiated by the subnational levels of government

\begin{tabular}{|c|c|c|c|c|}
\hline & $\begin{array}{l}\text { Land- } \\
\text { mark } \\
\text { rulings }\end{array}$ & Content of the challenge & Rulings & $\begin{array}{l}\text { Level of government } \\
\text { favored by the ruling }\end{array}$ \\
\hline Brazil & ADIn 926 & $\begin{array}{l}\text { Questions the constitution- } \\
\text { ality of Complementary Law } \\
77 / 93 \text { and Constitutional } \\
\text { Amendment 03/93, which } \\
\text { created the IPMF and imposed } \\
\text { a } 0.25 \% \text { tax on any financial } \\
\text { transaction. }\end{array}$ & $\begin{array}{l}\text { Considers certain provisions } \\
\text { unconstitutional provided that the } \\
\text { federal constitution already estab- } \\
\text { lishes the fiscal responsibilities of the } \\
\text { states and municipalities. The final } \\
\text { decision, an injunction, determines } \\
\text { that the states and municipalities as } \\
\text { federal constituent units should be } \\
\text { granted exemption from the IPMF. }\end{array}$ & Subnational \\
\hline Colombia & C-478/92 & $\begin{array}{l}\text { Challenges Law 38-1989 } \\
\text { claiming that it curtails the } \\
\text { fiscal autonomy of "depart- } \\
\text { ments" and municipalities. }\end{array}$ & $\begin{array}{l}\text { Declares Law 38-1989 constitutional } \\
\text { and establishes principles for conflict } \\
\text { resolution (hierarchy, homogeneity, } \\
\text { unity, and centralization of eco- } \\
\text { nomic affairs) concerning territorial } \\
\text { disputes. }\end{array}$ & National \\
\hline Spain & $\begin{array}{l}\text { STC } \\
76 / 1983\end{array}$ & $\begin{array}{l}\text { Contests the national Organic } \\
\text { Law on the Harmonization } \\
\text { of the Autonomic Process } \\
\text { (LOAPA), which establishes } \\
\text { common norms concerning } \\
\text { the implementation of the con- } \\
\text { stitutional competencies of the } \\
\text { Autonomous Communities. }\end{array}$ & $\begin{array}{l}\text { Pronounces that the LOAPA cannot } \\
\text { be enacted on the principle of har- } \\
\text { monization and as an organic law. } \\
\text { Furthermore, it considers unconsti- } \\
\text { tutional several of its articles (e.g., } \\
\text { Articles } 1 ; 2 ; 3 ; 4 ; 5.1,2 \text { and } 3 ; 7.1 \\
\text { and } 2 ; 9 ; 10 ; 22 \text { ), which, according to } \\
\text { the ruling, encroach on the constitu- } \\
\text { tionally guaranteed competencies of } \\
\text { the Autonomous Communities. }\end{array}$ & Subnational \\
\hline
\end{tabular}

In Brazil, the courts have been decisive on the fiscal front. The STF has increasingly decided on matters involving conflict between the executive and legislative branches at a subnational level, having a tendency to favor the executive branch. In other words, the STF has increasingly regulated subnational matters. In the Colombian case, indirect constitutional change has been felt in the post-constitutional setting up of the hierarchical mode of intergovernmental relations, whereas the constitution initially envisioned a decentralized mode of intergovernmental relations. In the Spanish case, under vague constitutional provisions on the territorial architecture, the courts have been able to establish a doctrine of intergovernmental relations that is notorious for delineating the distribution of responsibilities among the central government and the Spanish ACs.

Further evidence of the courts' lasting impact on intergovernmental relations is that over time they have created a pattern across the cases characterized by a gradual reduction of challenges, following the growing involvement of the courts. In Brazil, after 2005, the challenges brought to the courts by the state governors were substantially reduced. In Colombia, from 2001 onwards, approximately 10 years after the promulgation of its constitution, the number of challenges began to decline. And Spain, too, experienced a 
progressive reduction of unconstitutionality challenges in 1990, 10 years after the subnational challenges began to be admitted in court.

\section{Final Remarks and Extensions}

This article comes to the conclusion that whereas constitutional judicial review is being used as an instrument for intergovernmental dispute resolution, there are different institutional incentives behind the constitutional judicial review process. This variation in terms of patterns of reviews in Brazil, Colombia and Spain stems from the different institutional constraints influencing the judicialization of territorial relations in these countries.

In the comparison between the three cases, although there are variations in terms of how to file an unconstitutional challenge across the cases (e.g., the decision on whether concrete or abstract, applied a priori or a posteriori of the law enactment, distribution of power over the judicial review process among the supreme court and the subnational courts) there are some similarities among them, namely, the motivations behind the use of judicial review and the sustained role of courts on territorial issues.

In contentious political matters, such as issues involving more than one level of government, the uncertainty of the final outcome of the contention is often difficult to achieve through political mechanisms. In line with the main predictions put forward by Ginsberg (2003) and Hirschl (2004), constitutional courts in Brazil, Colombia and Spain work as an insurance mechanism for conflict resolution through different patterns. What determines these patterns are institutional differences such as inter-branch disputes in Brazil, the internal hierarchy of judicial decision-making in Colombia, and party competition in Spain.

The analysis of judicial review in the three countries answers the two central questions of this article. As far as the first question is concerned - how do national and subnational elites use intergovernmental mechanisms to enhance their own interests? -, in all the three countries the supreme courts are perceived by the political elites as legitimate forums for dispute settlement, and the process of judicial review is interpreted as a strategic choice in intergovernmental disputes. This is so even if courts have a tendency to favor the central government in dispute settlement.

In reference to the second question - how have supreme courts established themselves as pivotal institutions for intergovernmental dispute settlement? -, it is possible to infer that in the context of constant constitutional change, which applies to the three countries, the process of judicial review functions as an insurance against reforms that affect the interests of subnational politicians. Although the courts favor the central 
governments in their final ruling, it is often the case that the subnational elites use the unconstitutionality challenges as a strategic tool to exercise political pressure. Such pressure is exercised by delaying the implementation of the law being challenged and/ or to gain certain notoriety by being engaged in an intergovernmental dispute. This is particularly clear in the Spanish case. In Spain there is an unambiguous relationship between the growth of unconstitutionality challenges and the participation of regional parties in the national government coalition.

In Brazil, Colombia and Spain the judicialization of intergovernmental politics has been exercised in a context of institutional choice that has created an opportunity for subnational political actors to make use of judicial review mechanisms in situations where informal political institutions cannot settle conflicts. This article shows that constitutional judicial review has indeed been working as an insurance mechanism in times of intergovernmental conflict. One can generalize to all cases and say that territorial issues have become contentious enough in the three country cases, and touched on sufficiently fundamental territorial aspects, that courts have become the ultimate arbiter of contention.

In the attempt to build the relationship between constitutional judicial review and intergovernmental dynamics, new research should delve into further aspects of judicial review for further refinement of this relationship. Given it was beyond the scope of this article, the process of the courts' deliberation to reach the final ruling over judicial challenges has been overlooked in this analysis. A closer look at the deliberations might reveal the conflicts that exist behind the final courts' rulings. Another aspect of the judicial process that this article has paid little attention to is the response by national and subnational legislatives to the supreme courts' final rulings. Future research should concentrate on the consolidation of supreme courts as veto players in territorial affairs and how, in the long-run, courts become decisive actors in (un)balancing intergovernmental relations.

Revised by Priscila Moura

Submitted in October 2012

Accepted in June 2013

\section{References}

AGRANOFF, Robert and GALLARÍN, Juan Antonio R. (1997), Toward federal democracy in Spain: An examination of intergovernmental relations. Publius: The Journal of Federalism, vol.27, $\mathrm{n}^{\mathrm{0}} 4$, pp. 1-38. 
AJA FERNÁNDEZ, Eliseo. (1996), Los principales periodos de desarrollo del estado autonómico. VII Jornadas de Estudio La Unión Europea: Repercusiones de la Conferencia Intergubernamental de 1996, Logroño, 23-27 October.

ALEINIKOFF, Alexander T. (1997), Constitutional Law in the Age of Balancing. The Yale Law Journal, vol.96, no5, pp. 943-1005.

ARAÚJO, Alberto Luiz. (2005), O marco normativo do sistema de organização territorial no Brasil. In: Ordenamiento territorial en Brasil y España, edited by Antonio G. Moreira Maués and Itzíar Gómez Fernández. Valencia: Tirant la Blanch.

BRASIL. Supremo Tribunal Federal. http://www.stf.jus.br/portal/principal/principal.asp

ARAUJO, Luiz Alberto D. (2005), O marco normativo do sistema de organização territorial no Brasil. In Ordenamiento territorial en Brasil y España, edited by Antonio G. Moreira Maués and Itzíar Gómez Fernández.Valencia: Tirant la Blanch.

CAJAS SARRIÁ, Mário Alberto. (2007), Acerca de la interpretación en el control de las reformas constitucionales. Díkaion, 16, pp. 31-47.

CARRILO, Ernesto. (1997), Local Government and Strategies for Decentralization in the "State of the Autonomies". Publius: The Journal of Federalism, vol.27, nº4, pp. 39-64.

CARVALHO, Ernani Rodrigues. (2004), Em busca da judicialização da política no Brasil: apontamentos para uma nova abordagem. Revista de Sociologia e Política, no23, pp. 115-126.

COLOMBIA. Constitutional Court of Colombia. http://english.corteconstitucional.gov.co.

ELKINS, Zachary; GINSBURG, Tom Ginsburg; MELTON, James Melton. (eds.). (2009), The endurance of national constitutions. New York and Cambridge: Cambridge University Press.

EPSTEIN, Lee and KNIGHT, Jack. (1998), The Choices Justice Make. Washington, D.C: CQ Press.

FAlleti, Tulia G. (2010), Decentralization and Subnational Politics in Latin America. Cambridge: Cambridge University Press.

FERNÁNDEZ, Eliseo A. (1996), Los principales periodos de desarrollo del Estado autonómico. Anuario juridico de La Rioja, nº2, pp. 121-144.

FOX, Justin. and STEPHENSON, Matthew C. (2011), Judicial Review as a Response to Political Posturing. American Political Science Review, vol.105, nº2, pp. 397-414.

GAVARA DE CARA, Juan Carlos. (2011), Los efectos de la STC 31/2010 del estatuto de Autonomía de Cataluña: Las implicaciones para su normativa de desarrollo y los estatutos de otras Comunidades Autónomas. Teoría y realidad constitucional, no 27, pp. 239-289.

GINSBURG, Tom. (2003), Judicial Review in New Democracies: Constitutional Courts in Asian Cases. New York: Cambridge University Press.

GUARNERI, Carlo and PEDERZOLI, Patricia. (2002), From Democracy to Juristocracy? The Power of Judges: A Comparative Study of Courts and Democracy. Oxford: Oxford University Press. 
GUERRA, Luis López. (2000), Las Sentencias básicas del Tribunal Constitucional. Madrid: Centro de Estudios Políticos y Constitucionales.

GRABER, Mark A. (2005), Constructing Judicial Review. Annual Review of Political Science, vol.8, pp. 425-451.

GUILLÉN LOPEZ, Enrique Guillen. (2008), Judicial Review in Spain: The Constitutional Court. Loyola of Los Angeles Law Review, vol.41, n², pp. 529-562.

HALBERSTAM, Daniel. (2008), Comparative Federalism and the Role of the Judiciary. In: The Oxford Handbook of Law and Politics, edited by Keith E. Whittington, R. Daniel Kelemen, Gregory A. Caldeira. Oxford: Oxford University Press.

HEYWOOD, Paul. (1995), The Government and Politics of Spain. London: Palgrave Macmillan.

HIRSCHL, Ran. (2007), Towards Juristocracy: The Origins and Consequences of New Constitucionalism. Cambridge: Harvard University Press.

HIRSCHL, Ran. (2008), Judicialization of Politics. In: The Oxford Handbook of Law and Politics, edited by Keith E. Whittington, R. Daniel Kelemen, Gregory A. Caldeira. Oxford: Oxford University Press.

KAPISZEWSKI, Diana. (2011), Tactical Balancing: High Court Decision Making on Politically Crucial Cases. Law \& Society Review, vol.45, n², pp. 471-506.

LEONI, Eduardo L and RAMOS, Antonio P. (2006), Judicial Preferences and Judicial Independence in New Democracies: The Case of the Brazilian Supreme Court. New York: Columbia University.

LÓPEZ GUERRA, Luis. 2008, Las sentencias básicas del Tribunal Constitucional. Madrid: Centro de Estudios Políticos y Constitucionales.

MACIEL, Débora Alves and KOERNER, Andrei. (2002), Sentidos da Judicialização da Política: Duas Análises. Lua Nova, n57, pp.113-133.

MAUÉS, Antonio Gomes M. (2005), O Federalismo brasileiro na jurisprudência do Supremo Tribunal Federal (1988-2003). In: Direito constitucional contemporâneo: estudos em homenagem ao professor Paulo Bonavides. Belo Horizonte: Del Rey.

MINISTRY OF PUBLIC ADMINISTRATION (Spain). 2006, Conflictividad entre el estado y las comunidades autónomas. Madrid: Secretaría de Estado y Cooperación Territorial.

NIELSON, Daniel L. and SHUGART, Matthew S. (1999), Constitutional Change in Colombia: Policy Adjustment Through Institutional Reform. Comparative Political Studies, vol.32, nº3, pp. 313-341.

OLIVEIRA, Vanessa E. (2005), Judiciário e Privatizações no Brasil: Existe uma Judicialização da Política?. Dados - Revista de Ciências Sociais, vol.48, nº3, pp. 559-587.

OPESKIN, Brian R. (2001), Mechanisms for intergovernmental relations. International Social Science Journal, vol.53, nº167, pp.129-138.

RASCH, Bjorn E. and CONGLETON, Roger D. (2006), Amendment Procedures and Constitutional Stability. In: Democratic Constitutional Design and Public Policy, Analysis and Evidence, edited by Roger D. Congleton and Birgitta Swedenborg. Cambridge: MIT Press. 
REYES, Manuel A. (1986), ¿Estado jurisdiccional o autonómico? Revista Vasca de Administración Pública, nº16, pp. 7-12.

RÍOS-FIGUEROA, Julio. and TAYLOR, Matthew M. (2006), Institutional Determinants of the Judicialization of Policy in Brazil and Mexico. Journal of Latin America Studies, vol.38, $\mathrm{n}^{\circ} 4$, pp. 739-766.

RODRÍGUEZ-RAGA, Juan Carlos. (2008), Strategic Constitutional Review in Latin America: the case of Colombia, 1992-2006, Paper presented at the MPSA $66^{\text {th }}$ Annual National Conference, Chicago, IL.

RODRÍGUEZ-RAGA, Juan Carlos. (2011), Strategic Deference in the Colombian Constitutional Court, 1992-2006. In: Courts in America, edited by Gretchen Helmke and Julio Ríos-Figueroa. Cambridge: Cambridge University Press.

ROGERS, James R. (2001), Information and Judicial Review: A Signaling Game of JudicialLegislative Interaction. American Journal of Political Science, vol.45, nº 1, pp. 84-99.

ROSE-ACKERMAN, Susan; DESIERTO, Diane Alferez.; VOLOSIN, Natalia. (2011), HyperPresidentialism: Separation of Powers Without Checks and Balances in Argentina and the Philippines. Berkeley Journal of International Law, vol.29, nº1, pp. 246-333.

SANTISO, Carlos. (2003), Economic reform and judicial governance in Brazil: balancing independence with accountability. Democratization, vol.10, nº4, pp.161-180.

SPAIN. Spanish Constitution (1978), http://www.congreso.es/portal/page/portal/Congreso/ Congreso/Hist_Normas/Norm/const_espa_texto_ingles_0.pdf

SPAIN. MINISTRY OF PUBLIC ADMINISTRATION. (2006), Conflictividad entre el estado y las comunidades autónomas. Madrid: Secretaría de Estado y Cooperación Territorial.

SATO, MIYUKI. (2003), Judicial Review in Brazil. Nominal and Real. Global Jurist Advances, vol.3, nº1, pp. 1535-1661.

SOUZA, Celina. (1997), Constitutional engineering in Brazil: the politics of federalism and decentralization. London: St. Martin's Press.

STEIN, Ernesto; MARIANO, Tommasi; ECHEBARRÍA, Koldo; LORO, Eduardo; PAYNE, Mark. (2005), The politics of policies: Economic and social progress in Latin America. Washington: Inter-American Development Bank.

TATE, C. Neal. (1995), Why the expansion of judicial power. In: The global expansion of judicial power, edited by C. Neal Tate and Torbjörn Vallinder. New York: New York University Press.

TATE, C. Neal; VALLINDER, Torbjörn. (1995), Judicialization and the future of politics and policy. In: The global expansion of judicial power, edited by C. Neal Tate and Torbjörn Vallinder. New York: New York University Press.

TRIDIMAS, George. (2010), Constitutional Judicial Review and Political Insurance. European Journal of Law and Economics, n²9, pp. 81-101.

UPRIMNY, Rodrigo. (2003), The Constitutional Court and Control of Presidential Extraordinary Powers in Colombia. Democratization, vol.10, nº 4, pp. 46-69. 
UPRIMNY, Rodrigo. (2007), A judicialização da política na Colômbia: casos, potencialidades e riscos. Sur - Revista Internacional de Direitos Humanos, vol.4, nº6, pp. 52-69.

VALLINDER, Torbjörn. (1995), When Courts go Marching In. In: The global expansion of judicial power, edited by C. Neal Tate and Torbjörn Vallinder. New York: New York University Press.

VANBERG, Georg. (2001), Legislative-Judicial Relation: A Game-Theoretic Approach to Constitutional Review. American Journal of Political Science, vol.45, n²2, pp. 346-361.

VAUBEL, Roland. (2009), Constitutional courts as promoters of political centralization: lessons for the European Court of Justice. European Journal of Law and Economics, vol.28, no3, pp. 203-222.

VIANNA, Luis Werneck; CARVALHO, Maria Alice Rezende de; MELO, Manuel Palacios Cunha; BURGOS, Marcelo Baumann. (1999), A judicialização da política e das relações sociais no Brasil. Rio de Janeiro: Revan.

VIANNA, Luis Werneck; BURGOS, Marcelo Baumman; SALLES, Paula Martins. (2007), Dezessete anos de judicialização da política. Tempo Social - Revista de Sociologia da USP, vol.19, nº 2 , pp. 39-85.

VILLAAMIL, Óscar Alzaga. (2011), La nación como poder constituyente en los preámbulos de las leges superiores: el Estatuto de 2006 y la STC 31/2010. Teoría y Realidad Constitucional, no27, pp. 131-176.

\section{Notes}

1 The author wishes to thank Danielle da Costa Leite Borges, Elliot Parra Avila, Julio Ríos, Sabrina Ragone, Anna Margherita Russo, Giuseppe Martinico, and Maria Isabel Gonzalez Pascual for their valuable suggestions and comments.

2 It is possible to interpret Ginsburg's insurance argument from a more narrow perspective and apply this argument to transitions to democracy in which the members of the incumbent autocratic regime control the transition process. In such a situation, the courts are envisioned as having the role of protecting the incumbent elites in case they are faced with electoral defeat later on.

3 Other instruments of abstract review include the declaratory action of constitutionality, the direct unconstitutionality act due to omission (ADO) and petition for non-compliance with a fundamental precept. In addition, there are other mechanisms through which conflicts reach the STF, such as through the Extraordinary Appeals (Recursos Extraordinários - REs), which challenge lower court rulings, and the Writ of Mandamus (Mandato de Segurança - MS), both of which are concrete review mechanisms.

4 The Spanish constitution is difficult to amend because there is a requirement of a two-thirds majority in each chamber, followed by dissolution of parliament and ratification by referendum in order to approve an amendment. In contrast, to amend the Brazilian and Colombian constitutions, a lower threshold is required.

5 Data on the challenges in Brazil and Colombia were obtained from the webpages of the supreme court of each country (Brazil: www.stf.jus.br; Colombia: www.corteconstitucional.gov.co). The 
data on Spain was obtained from the report "Conflictividad entre el Estado y las Comunidades Autonómas" from the Ministry of Public Administration and Territorial Affairs (www.mpt.gob. es/publicaciones.html).

6 The standing right to judicial review is a noticeable difference among the three case studies. Spain has the most restricted access to the instrument of judicial review among the selected cases. In Brazil, the potential plaintiffs of a constitutional challenge are several institutional actors, including the head of the national and subnational executives, the national and subnational legislatives, the Prosecutor General and political parties. The Colombian procedure for judicial review is open to all individuals, who can become plaintiffs in the revision of a law or part of it.

7 Saliency will be based on secondary sources. These sources use either interviews or media accounts to determine the relevance of the court cases.

8 The STF maintains and updates detailed information on all the challenges that have reached the court since 1988. For more details, refer to the following webpage: http://www.stf.jus.br/ portal/peticaoInicial/pesquisarPeticaoInicial.asp (Accessed on April 20 $0^{\text {th }}, 2013$ ).

9 Kapiszewski (2011) identifies the 20 most salient challenges that reached the STF since its creation. These 20 cases, which include, for the most part, financial matters, were determined by scholarly sources, newspapers and interviews with experts.

10 In a similar challenge, ADIn 939, this time initiated by the National Confederation of Commerce Workers (CNTC), ruled in December 1993 that some articles of the challenged laws were unconstitutional.

11 One of the difficulties in identifying a Colombian pattern of judicialization of territorial politics stems from the lack of implementation of the territorial system in the country as envisioned by its constitution.

12 In Colombia, all the unconstitutionality challenges must be reviewed by the Attorney General, who must declare an opinion before the constitutional court declares its ruling. 